\title{
ENERGY AND GREENHOUSE GASES BALANCES OF COTTON FARMING IN IRAN: A CASE STUDY
}

\author{
Moslem Sami ${ }^{1}$, Habib Reyhani ${ }^{2}$ \\ ${ }^{1}$ Agriculture Bank of Iran, Isfahan, Iran \\ ${ }^{2}$ Department of Agricultural Machinery Engineering, Faculty of Agricultural Engineering and Technology, \\ University of Tehran, Karaj, Iran
}

\begin{abstract}
MOSLEM SAMI, HABIB REYHANI. 2018. Energy and Greenhouse Gases Balances of Cotton Farming In Iran: A Case Study. Acta Universitatis Agriculturae et Silviculturae Mendelianae Brunensis, 66(1):0101-0109.

This study evaluated the impacts of cotton farming on the climate changes in terms of energy and greenhouse gas (GHG) emission indices. Energy consumption pattern and sensitivity of energy inputs were evaluated and share of each input in GHG emissions was determined in the form of direct and indirect emissions for cotton farms in Golestan province of Iran. The total energy input and energy output were calculated to be 34,424.19 and 41,496.67 MJ/ha respectively. The share of fertilizers by $45.0 \%$ of total energy inputs was the highest. This was followed by energies of fuel (18.4\%) and irrigation (17.9\%) respectively. Fertilizers and fuels were also the biggest producers of GHGs in the farms with shares of 61.95 and $24.32 \%$ of total GHGs emission. Energy ratio, energy balance, energy intensity and energy productivity were found as 1.21, 7,072.48 MJ/ha, $9.79 \mathrm{MJ} / \mathrm{kg}$ and $0.10 \mathrm{~kg} / \mathrm{MJ}$, respectively. Results of sensitivity analysis indicated that the cotton production was more sensitive to energies of seed and human labour than other inputs and an additional use of $1 \mathrm{MJ}$ of each of these inputs would lead to a change in the yield by -0.75 and $0.73 \mathrm{~kg} / \mathrm{ha}$, respectively. The results also showed, in the process of cotton farming 897.80 and $1177.67 \mathrm{~kg} \mathrm{CO}_{2}$ - equivalent of direct and indirect GHG were emitted per hectare respectively.
\end{abstract}

Keywords: cotton, efficiency evaluation, energy analysis, GHG emission

\section{INTRODUCTION}

Agricultural production and input use in agriculture have increased remarkably in the recent years. More intensive use of inputs in agriculture has brought important environment problems and so efficient use of inputs has become important in terms of sustainable agricultural (Yilmaz et al., 2005). Evaluation of energy use pattern and greenhouse gas (GHG) emission is a valuable method for determining the degree of sustainabilityin production systems. If we looking for to increase agricultural productions while minimize agricultural impacts on future climate change, we should understand the current status of energy consumption pattern and GHG budget and their links to farms outputs. Assessment of energy flow and its indicators is widely used to analyze sustainability-related issues (Schroll, 1994). Kok et al. (2006) introduced energy as a proxy of the environmental load because of two main reasons. Firstly, energy use has impact on three environmental issues: resource depletion, local/regional environmental impact (acid rain) and global impact (greenhouse effect). Secondly, energy statistics are the best available environmental data and provide the possibility to calculate energy requirements in relation to the consumption. Production, storage and application of inputs in agricultural farms invoke combustion of fuels, which results in emission of GHGs. Agriculture accounts for one-fifth of the annual increase in anthropogenic greenhouse warming. Agriculture is the main source of non-carbon dioxide GHGs, emitting nearly $60 \%$ of nitrous oxide $\left(\mathrm{N}_{2} \mathrm{O}\right)$ and nearly $50 \%$ of methane $\left(\mathrm{CH}_{4}\right)$ (Smith et al., 2007). Significant decreases in GHG emissions and energy use in agricultural production process can be achieved through improved management of inputs consumption. 
Considerable research studies have been conducted on the energy use in different agricultural productions such as; grains (Asakereh et al., 2011; Moitzi et al., 2014; Sami et al., 2013), greenhouse crops (Firoozi et al., 2014; Heidari and Omid, 2011; Taki and Haddad, 2012), hay crops (Hassanzadeh Ghorttapeh et al., 2012), fruits (LoghmanpourZarini et al., 2013; Sami et al., 2011), vegetables (Pahlavan et al., 2012) etc. While due to shortage of information about gas emissions of agricultural inputs in the production processes, fewer comprehensive analyses have been conducted on gas emissions in agricultural. However, there are researches who tried to evaluate and analyze gas emissions of agricultural activities (e.g. Eshun et al., 2013; Sami et al., 2013; Lal, 2004).

In this study we analyzed the energy consumption pattern and GHG emission in cotton production in Iran. To perform a complete analysis on the energy consumption pattern, we used mathematical models. Determining the relationships between output yield and energy inputs in the form of mathematical models and evaluating the sensitivity of output yield to the energy inputs will help in determining not-efficient sectors and increasing the energy efficiency of farming systems.
The Cobb-Douglas production function was used to study the sensitivity and the relationship between energy inputs and cotton yield. The Cobb-Douglass function has been used as one of the best functions to investigate the relationship between energy inputs and production yield by several authors (e.g. Ghasemi Mobtaker et al., 2010; Mohammadi et al., 2010; Rafiee et al., 2010).

\section{MATERIALS AND METHODS}

\section{Case study region and data collection}

Data used in this research were gathered from 25 cotton farmers using face to face interviews in Gorgan county of Golestan province (Iran) during 2013-2014. Golestan province, with area of 7215 ha, is located in the northeastern of Iran within $36^{\circ} 44^{\prime}$ and $38^{\circ} 05^{\prime}$ north latitude and $53^{\circ} 51^{\prime}$ and $56^{\circ} 14^{\prime}$ east longitudes. The climate is temperate sub-humid with mild winters. Mean annual temperature and solar radiation are $17.6^{\circ} \mathrm{C}$ and $15.7 \mathrm{MJ} / \mathrm{m} *$ d respectively. Total annual precipitation is $607 \mathrm{~mm}$ (Soltani et al., 2013). The supplementary data on the farms were obtained from Ministry of Jihad-e-Agriculture of Iran. The simple random sampling method was

I: Coefficients of $\mathrm{CO}_{2}$-eq and energy of inputs and outputs in agricultural farms.

\begin{tabular}{|c|c|c|c|c|c|}
\hline Item & Unit & $\begin{array}{c}\text { Energy equivalent } \\
\text { (MJ/unit) }\end{array}$ & References & $\begin{array}{c}\mathrm{Co}_{2} \text {-eq coefficient } \\
\text { (kg/unit) }\end{array}$ & References \\
\hline $\begin{array}{l}\text { Machinery } \\
\text { (average) }\end{array}$ & $\mathrm{kg}$ & 139.02 & $\begin{array}{c}\text { Kitani (1998); } \\
\text { Pimentel and } \\
\text { Pimentel (1979) }\end{array}$ & 9.76 & $\begin{array}{l}\text { Adopted } \\
\text { from: Sami et al. } \\
\text { (2014) }\end{array}$ \\
\hline Diesel & l & 41.06 & Sami et al, (2014) & $\begin{array}{c}3.28 \text { (2.83 direct }+ \\
0.45 \text { indirect) }\end{array}$ & $\begin{array}{c}\text { Adopted } \\
\text { from: Sami et al. } \\
(2014)\end{array}$ \\
\hline Gasoline & 1 & 46.24 & Kitani (1998) & $\begin{array}{l}2.94 \text { (2.58 direct }+ \\
0.36 \text { indirect) }\end{array}$ & $\begin{array}{l}\text { Calculated } \\
\text { according: Macedo } \\
\text { et al. (2008) and } \\
\text { PEPD (2010) }\end{array}$ \\
\hline Electricity & $\mathrm{kWh}$ & 12.00 & Kitani (1998) & 0.87 & $\begin{array}{c}\text { Calculated } \\
\text { according: PEPD } \\
\text { (2010) }\end{array}$ \\
\hline $\mathbf{N}$ fertilizer & $\mathrm{kg}$ & 78.10 & Kitani (1998) & $\begin{array}{l}6.93 \text { (3.97 off-farm } \\
+2.96 \text { on-farm ) }\end{array}$ & $\begin{array}{c}\text { Adopted } \\
\text { from: Sami et al. } \\
\text { (2014) }\end{array}$ \\
\hline P fertilizer & $\mathrm{kg}$ & 17.40 & Kitani (1998) & 1.30 & Macedo et al. (2008) \\
\hline K fertilizer & $\mathrm{kg}$ & 13.7 & Kitani (1998) & 0.71 & Macedo et al. (2008) \\
\hline Micro fertilizers & $\mathrm{kg}$ & 120 & Mandal et al. (2002) & 0.66 & Macedo et al. (2008) \\
\hline Insecticide & $\mathrm{kg}$ or $\mathrm{l}$ & 310 & Barber (2004) & 29.00 & $\begin{array}{c}\text { Calculated } \\
\text { according: Macedo } \\
\text { et al. (2008) }\end{array}$ \\
\hline Herbicide & kg or l & 430.00 & Barber (2004) & 29.67 & $\begin{array}{c}\text { Adopted } \\
\text { from: Audsley et al. } \\
\text { (2009) }\end{array}$ \\
\hline Labour & $\mathrm{h}$ & 2.20 & $\begin{array}{l}\text { Pimentel and } \\
\text { Pimentel (1979) }\end{array}$ & - & - \\
\hline Water & $\mathrm{m}^{3}$ & 0.63 & Yaldiz et al. 1993 & - & - \\
\hline Seed & $\mathrm{kg}$ & 25.00 & $\begin{array}{l}\text { Dagistan et al. } \\
\text { (2009) }\end{array}$ & - & - \\
\hline
\end{tabular}


used to determine the survey sample size using Equation 1 (Ghasemi Mobtaker et al., 2010).

$$
\mathrm{n}=\frac{\mathrm{N}(\mathrm{s} \times \mathrm{t})^{2}}{(\mathrm{~N}-\mathrm{l}) \mathrm{d}^{2}+(\mathrm{s} \times \mathrm{t})^{2}}
$$

where $\mathrm{n}$ is required sample size, $\mathrm{N}$ is the number of holdings in target population, $\mathrm{s}$ is standard deviation, $d$ is acceptable error (permissible error was chosen as 5\%) and $t$ is confidence limit (1.96 in the case of $95 \%$ reliability).

\section{Energy budget calculation}

In this study the energy budget was calculated based on a mix of actual data from the farms and energy coefficients. Farms inputs and outputs were calculated and then, energy use values were calculated by multiplying the input and output components with their energy coefficients. The energy coefficients of inputs and outputs were adapted from different sources of estimations that best fit Iran conditions (Tab. I). Depending on the approach chosen, the human labor energy equivalent varies considerably (Mousavi - Avval et al., 2011b). Some researchers believe that labor energy equivalent must be adapted to the actual living conditions in the target region (Canakci et al., 2005). Labor energy equivalent used in this study includes only the muscle power used in different field operations of crop production. However different methods were presented for assessment of seed energy equivalent, in this study energy equivalent of seed was calculated according to total energy content of one kilogram of seed as bioenergy (Kitani, 1999).

Based on energy equivalents of the inputs and outputs, energy balance (MJ output minus MJ input), energy ratio (MJ output/MJ input), energy intensity (MJ input per kg of yield) and energy productivity (kg of yield per MJ input) were calculated as the indices of energy use efficiency (Singh, 2002).

The input energy is also classified into renewable and non-renewable; and direct and indirect forms. The sources of indirect energy include manure, fertilizers, pesticides, machineries, and seed; while the direct energy sources include human labour power, fuels and electricity. On the other hand, non-renewable energy includes fuels, electricity, fertilizers and pesticides; while renewable energy consists of human power, seed and manure (Demircan et al., 2006).

\section{Econometric model development}

The relationship between farms energy inputs and output yield was modeled using a prior mathematical function. The production function summarizes the process of conversion of factors into a particular commodity. To specify a fit function relation, the Cobb-Douglass production function was selected as the best function in terms of statistical significance and expected signs of parameters (Rafiee et al., 2010). The Cobb-Douglass function can be written in a linearized form as Equation 2 (Singh et al., 2004).

$$
\ln \mathrm{Y}_{\mathrm{i}}=a_{0}+\sum_{j=1}^{n} a_{j} \ln \left(x_{i j}\right)+u_{i}
$$

Where: $Y_{i}$ is the yield of the $i_{t h}$ farm, $X_{i j}$ is the $j_{t h}$ input used in the $i_{\text {th }}$ farm (here inputs are energies of human labour, machineries, fuels, pesticides, fertilizers, irrigation, and seed in MJ per hectare unit), $a_{0}$ is a constant term, $a_{j}$ is the regression coefficients of $j_{\text {th }}$ input, which is estimated from the model and $\mathrm{u}_{\mathrm{i}}$ is the error term in estimation of production of $i_{\text {th }}$ farm such that $\sum_{i=1}^{k} u_{i}=0$. When the energy input is zero, the crop production is also zero; therefore Equation 2 can be rewritten as Equation 3 (Singh et al., 2003):

$\ln Y_{i}=\sum_{j=1}^{n} a_{j} \ln \left(x_{i j}\right)+u_{i}$

In this functional form, $\mathrm{a}_{\mathrm{i}}$ represents the elasticity of output with respect to each input i. In other word, $\mathrm{a}_{\mathrm{i}}$ shows the percent change in output resulting from $1 \%$ increase in the $i_{\text {th }}$ input.

In this study the marginal physical productivity (MPP) method, based on response coefficients of the inputs was applied to analyze the sensitivity of energy inputs to the output yield. The results of sensitivity analysis show how the output may be affected by the change in each input usage. The MPP of an input presents the change in the yield output due to a unit change in the input, assuming all other factors are fixed at their geometric mean level. The MPP of various inputs was calculated using the $\mathrm{a}_{\mathrm{j}}$ of various energy inputs as Equation 4 (Singh et al., 2003).

$M p p_{x j}=\frac{G M(Y)}{G M\left(X_{j}\right)} \times a_{j}$

Where $\mathrm{MPP}_{\mathrm{xi}}$ is the marginal physical productivity of $j_{\text {th }}$ input, $a_{i}$ denotes the regression coefficient of $j_{\text {th }}$ input, $\mathrm{GM}(\mathrm{Y})$ is geometric mean of yield and $\mathrm{GM}\left(\mathrm{X}_{\mathrm{j}}\right)$ denotes the geometric mean of $\mathrm{j}_{\text {th }}$ input energy on per hectare basis.

In this study degree of return to scale was also calculated to investigate the effect of total energy inputs on output yield. Return to scale indicates changes in output due to a proportional change in all inputs (where all inputs increase by a constant factor). In a Cobb-Douglas production function, return to scale index is calculated by the sum of elasticity values derived in the form of regression coefficients (Rafiee et al., 2010). Returns to scale may be increasing $\left(\sum_{i=1}^{n} a_{i}>1\right)$, decreasing $\left(\sum_{i=1}^{n} a_{i}<1\right)$ or constant $\left(\sum_{i=1}^{n} a_{i}=1\right)$. 
After determining the Cobb-Douglas production function, technical efficiency of farms can be calculated using Equation 5 (Singh et al., 1998).

$$
\mathrm{TE}_{\mathrm{i}}=\exp \left[\left(u_{i}\right) /\left(\sum_{j=1}^{n} a_{j}\right)\right]
$$

Where $T E_{i}$ is the technical efficiency of the $i_{\text {th }}$ farm. The measure of technical efficiency compares the actual levels of input energy used to the level at which it would be used in $i_{\text {th }}$ farm to obtain the same output $Y$, but at the efficient level. In a farm if $\mathrm{TE}<1$, the frontier energy use is less than its actual use, if $\mathrm{TE}>1$, the frontier energy use is more than the actual energy use and if $\mathrm{TE}=1$, the actual energy input and the frontier energy use coincide (Singh et al., 2000).

\section{GHGs emission}

In agriculture, GHGs are emitted by use of fuels in farm equipment, (e.g. tillage, sowing, harvesting, water pumping, grain drying), production, transportation and application of farm inputs and also burning of biomass and decomposition of crop residues. Each input in agriculture may have two sources of emission including direct emission and indirect emission. Direct emission includes the total emissions released to the atmosphere during and after consumption of an input in the field and indirect emission includes GHG emissions from production, packaging and transporting of inputs. $\mathrm{CO}_{2}$ equivalent $\left(\mathrm{CO}_{2}-\mathrm{eq}\right)$ is a measure used to compare the emissions from various GHGs based upon their global warming potential (GWP), assuming a 100-year time horizon. The GWP is expressed in $\mathrm{kg} \mathrm{CO}_{2}$-eq, which is taken to be 1 for $\mathrm{CO}_{2}, 298$ for $\mathrm{N}_{2} \mathrm{O}$ and 25 for $\mathrm{CH}_{4}$ (IPCC, 2006). The $\mathrm{CO}_{2}$-eq for a gas is derived by multiplying the amount of the gas by the GWP of the gas. Conversion coefficients are calculated for each farm input based on its GHG emission during its production or/and consumption and can be expressed in $\mathrm{kg} \mathrm{CO}_{2}$-eq per weight of input (Sami et al., 2014). Used conversion coefficients in this study are presented in Tab. I. The calculation of emissions from electricity use was based on the ratio of different energy sources used in the generation process of electricity in Iran. On-farm emission of fertilizers involves emissions from soil denitrification and nitrification processes in the field after distribution of fertilizers (direct emission) (Sami et al., 2014). As discussed by Sami et al. (2014) we did not take into account carbon cycle in the farms since the amount of $\mathrm{C}$ lost via harvested crops is considered to be replaced by $\mathrm{C}$ uptake in the following crops and there is no significant long-term accumulation of $\mathrm{C}$ in crops products.

\section{RESULTS AND DISCUSSION}

\section{Energy consumption pattern}

Used inputs and related energy equivalents for the cotton production in the studied area are presented in Tab. II. As it can be seen, the share of total fertilizers energy from the total energy input was about $45.0 \%$ (15392 MJ/ha). This indicates that fertilizers had the most significant contribution in the cotton production between all inputs. Nitrogen was the dominant energy consumer

II: Amount of inputs and their energy equivalents for cotton production

\begin{tabular}{lccc}
\hline \multicolumn{1}{c}{ Item } & Quantity (Unit/ha) & $\begin{array}{c}\text { Total energy equivalent } \\
\text { (MJ/ha) }\end{array}$ & Percentage of total \\
\hline Labour & 1264.8 & 2783 & 8.1 \\
Machinery & 13.4 & 1856 & 5.4 \\
Fuel & 150.6 & 6353 & 18.5 \\
Diesel & 3.6 & 6185 & 18.0 \\
Gasoline & & 168 & 0.5 \\
Irrigation & 93.3 & 6160 & 17.9 \\
Electricity for pumping & 8000.0 & 1120 & 3.3 \\
Water & & 5040 & 14.6 \\
Fertilizers & 156.3 & 15392 & 44.7 \\
N fertilizer & 125.0 & 12203 & 35.5 \\
P fertilizer & 55.0 & 2175 & 6.3 \\
K fertilizer & 2.2 & 754 & 2.2 \\
Others & & 260 & 0.8 \\
Pesticides & 1.1 & 944 & 2.7 \\
Insecticide & 1.4 & 350 & 1.0 \\
Herbicide & 37.5 & 593 & 1.7 \\
Seed & & 938 & 2.7 \\
\hline
\end{tabular}


among fertilizers and almost 79.3\% (12203 MJ/ha) of the total consumed energy by fertilizers associated with the nitrogen fertilizer. This high rate of energy consumption was mostly due to the high embodied energy coefficient of nitrogen fertilizer and also the high rate of nitrogen fertilizer consumption. Fertilizer was reported as the most demanding energy input by many researchers in different agricultural products (e.g. in cotton by Dagistan et al., 2009; in wheat by Strnad and Miša, 2016; in potato by Mohammadi et al., 2008 and in canola by Mousavi - Avval et al., 2011A). The second most energy demanding input in the cotton farming was fuel with a share of $18.4 \%(6,352 \mathrm{MJ} / \mathrm{ha})$ of total input energy. Consumed fuel in the farms included the gasoline fuel for the knapsack sprayer and the diesel fuel for other mechanical operations. After fuels, the energy for irrigation also had a considerable share of total input energy with proportion of $17.9 \%(6,160 \mathrm{MJ} / \mathrm{ha})$. The irrigation energy included the energy of electricity for water pumping and energy embodied in water handling and distribution equipment. Many past studies also reported the irrigation and fuel as two of the most energy consuming inputs (Dagistan et al., 2009; Mohammadi et al., 2008; Rafiee et al., 2010). The shares of other inputs from total input energy were relativity low.

Calculated indices regarding farm energy analysis are reflected in Tab. III. The average annual yield of farms was estimated as 3,517 kg/ha. The total average energy requirement for producing of this yield was 34,424 MJ/ha, which was smaller than the total output energy (41,497 MJ/ha). Therefore, energy ratio (1.21) was higher than one and energy balance (7,072 MJ/ha) was positive, indicating that cotton production in the surveyed region was efficient in terms of energy. The crop yield in the studied region was in the range of average cotton yield in other parts of the world. For example, the yields of $3,113 \mathrm{~kg} / \mathrm{ha}$ by Yilmaz et al. (2005) and 3,917 kg/ha by Dagistan et al, (2009) were reported. Nevertheless, very different ranges of energy ratio were reported in past studies for cotton (e.g. 2.4 by Dagistan et al., 2009; 9.8-12.0 by Singh et al., 2000; 1.7 by Tsatsarelis, 1991 and $0.7-0.8$ by Yilmaz et al., 2005).

Energy productivity of farms was obtained as $0.1 \mathrm{~kg} / \mathrm{MJ}$. This means that $0.1 \mathrm{~kg}$ of output was obtained per unit of input energy. The average energy intensity of studied farms was $9.7 \mathrm{MJ} / \mathrm{kg}$. This index shows that $9.7 \mathrm{MJ}$ of energy was used for production of one kilogram of cotton. Of total input energy, 23,375 MJ/ha (69.5\%) was indirect and 10,255 MJ/ha (30.5\%) was direct energy. The high rate of indirect energy consumption in the cotton production means that cotton production in the studied region was intensive. The total energy input of studied farms could be also classified as renewable energy (11.1\%) and non-renewable energy (88.9\%). In several past studies the ratio of non-renewable energy was also reported greater than that for renewable energy (e.g. Asakereh et al., 2011; Hassanzadeh Ghorttapeh et al., 2012; Loghmanpour-Zarini et al., 2013). The high rate of non-renewable energy has negative effects on the sustainability of agricultural productions (Dagistan et al., 2009). Therefore, a reduction in the total non-renewable energy ratio, especially in fertilizers and fuels consumption would help to improve the sustainability of cotton production.

\section{Econometric model estimation of cotton production}

A Cobb-Douglas production function was specified and estimated using Ordinary Least Square estimation technique to investigate the relationship between inputs and cotton yield. The regression coefficients of obtained model are presented in Tab. IV. The highest effect on the output belonged to human labour energy (0.50) that its impact on the yield was significant at $5 \%$ level. This indicates that increasing $10.0 \%$ in the energy of human labour led to $5.0 \%$ increase in cotton output in present condition. Other than human labour energy, the impacts of other inputs on the cotton yield in the case study were not statistically significant. After labour energy, the highest impact belonged to seed (-0.18), followed by irrigation (-0.16), fertilizers

III: Calculated indices for cotton production in Iran

\begin{tabular}{lcc}
\hline \multicolumn{1}{c}{ Item } & Unit & Quantity (\%) \\
\hline Output yield & $\mathrm{kg} / \mathrm{ha}$ & $3,516.7$ \\
Total energy output & $\mathrm{MJ} / \mathrm{ha}$ & 41,497 \\
Energy ratio & - & 1.21 \\
Energy balance & $\mathrm{MJ} / \mathrm{ha}$ & 7,073 \\
Energy intensity & $\mathrm{MJ} / \mathrm{kg}$ & 9.8 \\
Energy productivity & $\mathrm{kg} / \mathrm{MJ}$ & 0.1 \\
Direct energy & $\mathrm{MJ} / \mathrm{ha}$ & $10,255(29.8)$ \\
Indirect energy & $\mathrm{MJ} / \mathrm{ha}$ & $24,169(70.2)$ \\
Renewable energy & $\mathrm{MJ} / \mathrm{ha}$ & $3,720(10.8)$ \\
Non-renewable energy & $\mathrm{MJ} / \mathrm{ha}$ & $30,704(89.2)$ \\
Total input energy & $\mathrm{MJ} / \mathrm{ha}$ & $34,424(100.0)$ \\
\hline
\end{tabular}


(0.08) and fuels (0.08). The contributions of other inputs (pesticides and machinery) were ignorable. Our result is according to that of Mohammadi et al, (2010), who reported human labour as the most significant input impacting in improving the yield of kiwifruit. Similar result was also report by Pahlavan et al. (2012) in basil. The value of return to scale for the model was calculated as 0.34 . This implies that $10.0 \%$ increase in all energy inputs would lead to $3.4 \%$ increase in the cotton production.

For data used in this study, autocorrelation was tested using Durbin-Watson method (Singh et al., 2004). Durbin-Watson value was measured as 2.33 for the model, indicating that there was no autocorrelation in the estimated model. The MPP values of model variables are shown in the last column of Tab. IV. As it can be seen, MPPs of seed, human labour and pesticides inputs were found to be $-0.75,0.73$ and 0.25 , respectively. This indicates that an increase of $1 \mathrm{MJ}$ in energy input of seed, would lead to a decrease in yield by -0.75 , and an increase of $1 \mathrm{MJ}$ in each input of human labour and pesticides energy would lead to an additional increase in yield by 0.73 and $0.25, \mathrm{~kg} / \mathrm{ha}$, respectively. Negative MPP value of seed shows that additional units of this input are contributing negatively to production. This may be due to adverse influences of high plant density on growth and yield of crops. As cotton farming in the studded farms is semi-mechanized and mostly depend human work, high value of MPPs for human labour may implicate the need for better management and more use of workers in the farms. MPPs values near the zero for machinery and fertilizer may show the optimum use of this inputs.

Fig. 1 shows the distribution of the studied farms according to their technical efficiency values. About $52 \%$ of the farms (13) used less energy than the frontier level at which they can attain the potential yield (TE $<75 \%$ ). In these farms, yield can be improved by using an increase in the total input energy. Only $8 \%$ of farms (2) operated close to the frontier level $(75<\mathrm{TE}<100 \%)$. In a high percentage of farms (40\%), it was operated at very high levels of energy input consumption compared to the frontier level ( $100 \%>$ TE). However in these farms, the maximum potential yield was produced according to the prediction function, a high rate of energy was lost in these production systems. In these farms, very opportunities are to decrease the input energy without any reduction in the total output yield. Similar results is mentioned also in the past study by Ržonca et al. (2005) who showed energy efficiency has decreased by increasing the input energies in grasslands.

IV: Econometric model estimation results of inputs

\begin{tabular}{|c|c|c|c|}
\hline $\begin{array}{c}\text { Endogenous variable: yield } \\
\text { Exogenous variables }\end{array}$ & Coefficient & $t$-ratio & MPP \\
\hline \multicolumn{4}{|c|}{ Model; $\ln Y_{i}=a_{1} \ln X_{1}+a_{2} \ln X_{2}+a_{3} \ln X_{3}+a_{4} \ln X_{4}+a_{5} \ln X_{5}+a_{6} \ln X_{6}+a_{7} \ln X_{7}+e_{i}$} \\
\hline Labour & 0.499 & 2.150 & 0.725 \\
\hline Machinery & -0.004 & -0.015 & -0.009 \\
\hline Fuels & 0.079 & 0.299 & 0.044 \\
\hline Irrigation & -0.155 & -0.693 & -0.093 \\
\hline Fertilizers & 0.080 & 0.352 & 0.020 \\
\hline Pesticides & 0.025 & 0.100 & 0.245 \\
\hline Seed & -0.181 & -0.765 & -0.746 \\
\hline Durbin-Watson & 2.326 & & \\
\hline $\mathbf{R}^{2}$ & 0.385 & & \\
\hline Return to scale & 0.343 & & \\
\hline
\end{tabular}

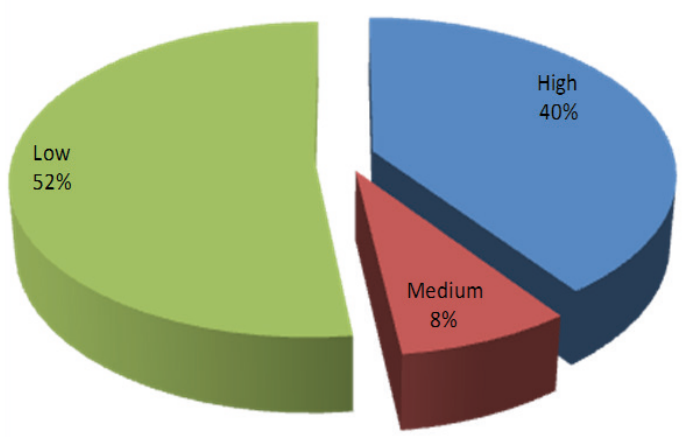

1: Technical efficiency rating of cotton farms 


\section{GHG emission evaluation}

The amounts of GHG emitted by each input in the cotton farming are presented in Tab. V. Most of emissions from cotton production belonged to indirect emissions (56.7\%). Fuels and $\mathrm{N}$ fertilizer were the only sources of direct emissions in the farms. Nevertheless, the share of direct emission from total emission in the farms was considerable and $43.3 \%$ of total emission was direct emission and the rest was indirect emission. Fertilizers in the farms were the biggest air pollutant in terms of total GHG emissions with a share of $61.9 \%$ of total $\mathrm{CO}_{2}-\mathrm{eq}$ emission (1285.80 kg/ha). Fertilizers were also the biggest direct producers of GHG in the farms with a share of $51.5 \%$ (462.50 kg CO $\left.\mathrm{CO}_{2}-\mathrm{eq} / \mathrm{ha}\right)$ of total direct emission. Nitrogen was the dominant source of GHG emissions among fertilizers and almost 84.2\% of the total $\mathrm{CO}_{2}$-eq emission from fertilizers use and $52.2 \%$ of total GHG emission from farming systems belonged to it. About $57.3 \%(462.50 \mathrm{~kg}$ $\mathrm{CO}_{2}-\mathrm{eq} / \mathrm{ha}$ ) of nitrogen fertilizer emission was indirect emission and the rest (42.7\%) was direct emission $\left(\mathrm{N}_{2} \mathrm{O}\right.$ emission from soil denitrification and nitrification processes). One strategy for reducing the adverse effects of fertilizers on environment is to apply no more fertilizers than the crops can use during the growing season. Nearly all cotton farmers in the studied area used the nutrients based on their past experiences. Correct measurement of nutrients requirements based on expected yield and nutrients levels using soil test would reduce the consumption of fertilizers and their unwanted effects on the environment (especially GHG emissions). After fertilizers, the fuels had the highest share from the total emission (24.3\%). Fuels were also the second air pollutant in terms of direct emission with a share of $48.5 \%$ (435.30 $\mathrm{kg} \mathrm{CO}$-eq/ha) of total direct emission. Other inputs hadn't considerable shares from the total GHG emission in the studied farms. In the process of cotton cultivation, 897.8, 1177.7 and $2075.5 \mathrm{~kg} \mathrm{CO}_{2}$-eq of direct, indirect and total GHG were emitted per hectare respectively.

V: The shares of inputs from the total GHG emission in the farms

\begin{tabular}{|c|c|c|c|c|c|c|}
\hline Item & \multicolumn{2}{|c|}{ Direct emission } & \multicolumn{2}{|c|}{ Indirect emission } & \multicolumn{2}{|c|}{ Total emission } \\
\hline Machinery & 0.0 & 0.0 & 130.3 & 11.1 & 130.3 & 6.3 \\
\hline Fuels & 435.30 & 48.5 & 69.4 & 5.9 & 504.7 & 24.3 \\
\hline Gasoline & 9.4 & 1.0 & 1.3 & 0.1 & 10.7 & 0.5 \\
\hline Irrigation & 0.0 & 0.0 & 80.9 & 6.9 & 80.9 & 3.9 \\
\hline Electricity for pumping & 0.0 & 0.0 & 80.9 & 6.9 & 80.9 & 3.9 \\
\hline Water & 0.0 & 0.0 & 0.0 & 0.0 & 0.0 & 0.0 \\
\hline K fertilizer & 0.0 & 0.0 & 39.1 & 3.3 & 39.1 & 1.9 \\
\hline Others & 0.0 & 0.0 & 1.4 & 0.1 & 1.4 & 0.1 \\
\hline Pesticides & 0.0 & 0.0 & 73.7 & 6.3 & 73.7 & 3.6 \\
\hline Insecticide & 0.0 & 0.0 & 32.8 & 2.8 & 32.8 & 1.6 \\
\hline Herbicide & 0.0 & 0.0 & 40.9 & 3.5 & 40.9 & 1.9 \\
\hline Seed & 0.0 & 0.0 & 0.0 & 0.0 & 0.0 & 0.0 \\
\hline Total emission & 897.8 & 100.0 & 1177.7 & 100.0 & 2075.5 & 100.0 \\
\hline
\end{tabular}

\section{CONCLUSIONS}

In this study the energy consumption pattern and GHG emissions in the cotton production and their relationship with the total output yield were analyzed in Iran. According to our results the cotton production was very dependent on the energies of fertilizers, fuels and irrigation, so that about $90 \%$ of total input energy belonged to these inputs. Nevertheless, the output yield was more sensitive to the energies of human labour and seed than other inputs and impacts of these inputs on the output yield were higher than other inputs. The cotton production was very dependent on the non renewable form of energy and the share of non renewable energy from the total input energy was very greater than renewable energy. Only a few numbers of farmers consumed energy efficiency and 
operated close to the frontier level. This suggests that the energy consumption pattern in the studded farms should be revised. The results also showed that during the process of cotton farming $2075.5 \mathrm{~kg}$ $\mathrm{CO}_{2}-\mathrm{eq} / \mathrm{ha}$ of $\mathrm{GHG}$ was emitted which most of it was indirect emission. Fertilizers and fuels were the biggest producers of direct and total GHG in the farms.

However there were done many studies on energy equivalents of different inputs in agricultural crops, it seems there is no study on the input energy costs for Iran. In this study, energy cost of inputs and practices were adapted from different sources of estimations that best fit Iran conditions. This reveals the need for studies to calculate the energy equivalents according to Iran situation. Furthermore, cottonseed as a source of bioenergy has low economic benefit in direct use and evaluation of energy budget of bio-oil production from cottonseed is suggested for future researches.

\section{REFERENCES}

ASAKEREH, A., SAFAIENEJAD, M. and SAMI, M. 2011. Energy and economic analysis of dry farming chickpea in Iran a case study: Lorestan province. Journal of Agricultural Technology, 7(3): 547-555.

AUDSLEY, E., STACEY, K., PARSONS, D. J. and WILLIAMS, A. G. 2009. Estimation of the Greenhouse Gas Emissions from Agricultural Pesticide Manufacture and Use. Cranfield, UK: Cranfield University.

BARBER, A. 2004. Seven Case Study Farms: Total Energy \& Carbon Indicators for New Zealand Arable $\sigma$ Outdoor Vegetable Production. AgriLINK New Zealand Ltd.

CANAKCI, M., TOPAKCI, M., AKINCI, I. and OZMERZI, A. 2005. Energy use pattern of some field crops and vegetable production: case study for Antalya Region, Turkey. Energy Conversion and Management, 46(4): 655-666.

DAGISTAN, E., AKCAOZ, H., DEMIRTAS, B. and YILMAZ, Y. 2009. Energy usage and benefit-cost analysis of cotton production in Turkey. African Journal of Agricultural Research, 4(7): 599-604.

DEMIRCAN, V., EKINCI, K., KEENER, H. M., AKBOLAT, D. and EKINCI, C. 2006. Energy and economic analysis of sweet cherry production in Turkey: a case study from Isparta province. Energy Conversation Management, 47(13): 1761-1769.

ESHUN, J. F., APORI, S O. and WEREKO, E. 2013. Greenhouse gaseous emissions and energy analysis in rice production systems in Ghana. African Crop Science Journal, 21(2): 119-25.

FIROOZI, S., SHEIKHDAVOODI, M. and SAMI, M. 2014. Evaluation the ability of different artificial intelligence-based modeling techniques in prediction of yield using energy inputs data of farms. Journal of Life Science and Biomedicine, 4(3): 214-220.

GHASEMI MOBTAKER, H. G., KEYHANI, A., MOHAMMADI, A., RAFIEE, S. and AKRAM, A. 2010. Sensitivity analysis of energy inputs for barley production in Hamedan Province of Iran. Agriculture, Ecosystems and Environment, 137(3): 367-372.

HASSANZADEH GHORTTAPEH, H., TAHERIFARD, E. and GERAMI, F. 2012. Energy efficiency in alfalfa (medicago sativa L.) production system in North West of Iran (case study: Mahabad City) Annals of Biological Research, 3(5): 2469-2473.

HEIDARI, M D. and OMID, M. 2011. Energy use patterns and econometric models of major greenhouse vegetable productions in Iran. Energy, 36(1): 220-225.

EGGLESTON, H. S. BUENDIA, L. MIWA, K. NGARA, T. and TANABE, K. (Eds.) 2006. 2006 IPCC Guidelines for National Greenhouse Gas Inventories. Hayama: Institute for Global Environmental Strategies.

KITANI O. 1999. Energy and biomass engineering. In: CIGR handbook of agricultural engineering. St. Joseph, MI: ASAE.

KITANI, O. 1998. Energy and environment in agricultural engineering research. In: International Engineering Conference Bangkok. Bangkok: Thai Society of Agricultural Engineering.

KOK, R., BENDERS, R M J. and MOLL, H. C. 2006. Measuring the environmental load of household consumption using some methods based on input-output energy analysis: a comparison of methods and a discussion of results. Energy Policy, 34(17): 2744-2761.

LAL, R. 2004. Carbon emissions from farm operations. Environment International, 30: 981-90.

LOGHMANPOUR-ZARINI, R., YAGHOUBI, H. and AKRAM, A. 2013. Energy use in citrus production of Mazandaran province in Iran. African Crop Science Journal, 21(1): 61-65.

MACEDO, I. C., JOAQUIM SEABRA, J. E. A. and SILVA, J. E. A. R. 2008. Green house gases emissions in the production and use of ethanol from sugarcane in Brazil: the 2005/2006 averages and a prediction for 2020. Biomass Bioenergy, 32: 582-595.

MANDAL, K. G., SAHA, K. P., GHOSH, P. K., HATI, K. M. and BANDYOPADHYAY, K. K. 2002. Bioenergy and Economic Analysis of Soybean-based Crop Production Systems in Central India. Biomass Bioenergy, 23(5): 337-345.

MOHAMMADI, A., RAFIEE, S., MOHTASEBI, S. S. and RAFIEE, H. 2010. Energy inputs-yield relationship and cost analysis of kiwifruit production in Iran. Renewable Energy, 35(5): 1071-1075.

MOHAMMADI, A., TABATABAEEFAR, A., SHAHIN, SH., RAFIEE, SH. and KEYHANI, A. 2008. Energy use and economical analysis of potato production in Iran a case study: Ardabil province. Energy Conversion and Management, 49(12): 3566-3570. 
MOITZI, G., MARTINOV, M., NOZDROVICKY, L., NAGHIU, A. and GRONAUER, A. 2014. Energy Use and Energy Efficiency in Selected Arable Farms in Central and South Eastern Europe. Agriculturae Conspectus Scientificus, 79(1): 51-56.

MOUSAVI-AVVAL, S. H., RAFIEE, S. H., JAFARI, A., and MOHAMMADI, A. 201la. Improving energy use efficiency of canola production using data envelopment analysis (DEA) approach. Energy, 36(5): 2765-2772.

MOUSAVI-AVVAL, S. H., RAFIEE, SH., JAFARI, A. and MOHAMMADI, A. 201lb. Energy flow modeling and sensitivity analysis of inputs for canola production in Iran. Journal of Cleaner Production, 19(13): 1464-1470.

PAHLAVAN, R., OMID, M. and AKRAM, A. 2012. The relationship between energy inputs and crop yield in greenhouse basil production. Journal of Agricultural Science and Technology, 14(6): 1243-1253.

PIMENTEL, D. and PIMENTEL, M. 1979. Food Energy and Society. Resource and Environmental Science Series. London: Edward Arnold Publ.

POWER AND ENERGY PLANNING DEPARTMENT (PEPD). 2010. Energy balance Sheet of Iran. Tehran., Iran: Iranian Military of Energy.

RAFIEE, S., MOUSAVI AVVAL, S. H. and MOHAMMADI, A. 2010. Modeling and sensitivity analysis of energy inputs for apple production in Iran. Energy, 35(8): 3301-3306.

RŽONCA, J., MITRUŠKOVÁ, M., POZDÍŠEK, J., POSPIŠIL, R., MIČOVÁ, P., ŠTÝBNAROVÁ, M. and SVOZILOVÁ, M. 2005. Energy analysis of various grassland utilisation systems. Acta Universitatis Agriculturae Et Silviculturae Mendelianae Brunensis, 53(4): 117-126.

SAMI, M., SHIEKHDAVOODI, M. and ASAKEREH, A. 2011. Energy use in apple production in the Esfahan province of Iran. African Crop Science Journal, 19: 125-130.

SAMI, M., SHIEKHDAVOODI, M. J., ALMASSI, M. and MARZBAN, A. 2013. Assessing the sustainability of agricultural production systems using fuzzy logic. Journal of Central European Agriculture, 14(3): 318-330.

SAMI, M., SHIEKHDAVOODI, M. J., PAZHOHANNIYA, M. and PAZHOHANNIYA, F. 2014. Environmental comprehensive assessment of agricultural systems at the farm level using fuzzy logic: A case study in cane farms in Iran. Environmental Modelling and Software, 58: 95-108.

SCHROLL, H. 1994. Energy-flow and ecological sustainability in Danish agriculture. Agriculture Ecosystems and Environment, 5: 301-310.

SINGH, G., SINGH, S. and SINGH, J. 2004. Optimization of energy inputs for wheat crop in Punjab. Energy Conversion and Management, 45: 453-465.

SINGH, H., MISHRA, D., NAHAR, N M. and RANJAN, M. 2003. Energy use pattern in production agriculture of a typical village in arid zone India: part II. Energy Conversion and Management, 44(7): 1053-1067.

SINGH, JM. 2002. On farm energy use pattern in different cropping systems in Haryana India. Master of Science Thesis. International Institute of Management, University of Flensburg, Germany.

SINGH, S., SINGH, S., MITTAL, J. P. and PANNU, C. J. S. 1998. Frontier energy use for the cultivation of wheat crop in Punjab. Energy Conversation Management, 39 (5-6): 485-491.

SINGH, S., SINGH, S., PANNU, C. J. S. and SINGH, J. 2000. Optimization of energy input for raising cotton crop in Punjab. Energy Conversion and Management, 41(17): 1851-1861.

SMITH, P., MARTINO, D., CAI, Z., GWARY, D., JANZEN, H H., KUMAR, P., MCCARL, B., OGLE, S., O'MARA, F., RICE, C., SCHOLES, R. J., SIROTENKO, O., HOWDEN, M., MCALLISTER, T., PAN, G., ROMANENKOV, V., ROSE, S., SCHNEIDER, U. and TOWPRAYOON, S. 2007. Chapter 8: Agriculture. In: METZ, B., DAVIDSON, O. R., BOSCH, P. R, DAVE, R. and MEYER, L. A. (Eds.). Contribution of Working Group III to the Fourth Assessment Report of the Intergovernmental Panel on Climate Change. Cambridge, United Kingdom and New York, USA: Cambridge University Press.

SOLTANI, A., RAJABI, M. H., ZEINALI, E. and SOLTANI, E. 2013. Energy inputs and greenhouse gases emissions in wheat production in Gorgan Iran. Energy, 50(C): 54-61.

STRNAD, L. and MIŠA P. 2016. Energy Use of Different Farming Systems in Long-Term Trial. Acta Universitatis Agriculturae et Silviculturae Mendeliande Brunensis, 64 (5): 1667-1674.

TAKI, M. and HADDAD, M. 2012. A novel method with multilayer feed-forward neural network for modeling output yield in agriculture. International Journal of Modern Agriculture, 1 (1): 13-23.

TSATSARELIS, C.A. 1991. Energy requirements for cotton production in central Greece. Journal of Agricultural Engineering Researches, 50: 239-246.

YALDIZ, O., OZTURK, H. H., ZEREN, Y. and BASCETINCELIK, A. 1993. Energy usage in production of field crops in Turkey. In: 5th Int. Cong. On Mechanization and Energy Use in Agriculture, 11-14 Oct, 1993, Kusadasi, Turkey.

YILMAZ, I., AKCAOZ, H. and OZKAN, B. 2005. An analysis of energy use and input costs for cotton production in Turkey. Renewable Energy, 30: 145-155. 